\title{
Opodatkowanie dochodów osób fizycznych z pracy najemnej - analiza stanu obecnego i proponowane kierunki reformy
}

\begin{abstract}
Taxation of the income from natural persons' contract work. Current status and suggested reform: The article looks at the taxation of income from natural persons' contract work or similar arrangements. The author argues that it is essential to clearly define the concept of contract work in the Polish tax legislation as a general category incorporating various legal titles concerning the work undertaken by an employee. The author discusses the complex structure of income sources and main income types earned by employees, and identifies legal problems caused by this variety and gives some recommendations.
\end{abstract}

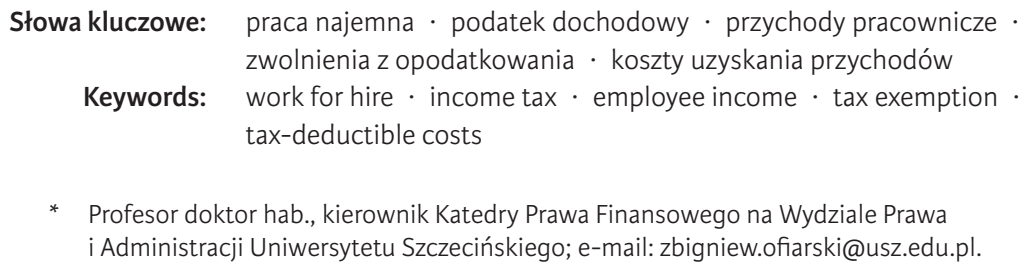

\section{Wstęp}

Zasady opodatkowania dochodów pochodzących z tzw. pracy najemnej zostały ukształtowane przepisami ustawy z 26 lipca $1991 \mathrm{r}$. o podatku dochodowym od osób fizycznych (t.j. Dz.U. 2018, poz. 200, ze zm.; dalej: u.p.d.f.). Jej wejście w życie doprowadziło do ujednolicenia zasad opodatkowania dochodów (wynagrodzeń) osiąganych $\mathrm{z}$ tego typu pracy. W miejsce dotychczas stosowanych kilku podatków (podatku od wynagrodzeń ${ }^{1}$, podatku od płac ${ }^{2}$, podatku

1 Ustawa z 4 lutego 1949 r. o podatku od wynagrodzeń, Dz.U. nr 7, poz. 41, ze zm.

2 Ustawa z 26 lutego 1982 r. o opodatkowaniu jednostek gospodarki uspołecznionej, Dz.U. 1987, nr 12, poz. 77, ze zm. 
wyrównawczego ${ }^{3}$, podatku dochodowego ${ }^{4}$ ) wprowadzono jeden, uniwersalny podatek dochodowy, w którego konstrukcji wykorzystano niektóre rozwiązania stosowane $\mathrm{w}$ dotychczas obowiązujących podatkach. Zniesiono również, charakterystyczny dla okresu sprzed roku 1992, podział sektorowy stosowany w opodatkowaniu dochodów z pracy najemnej. Odmienne reguły obowiązywały w zakresie opodatkowania takich dochodów osiąganych przez pracowników zatrudnionych w sektorze uspołecznionym oraz nieuspołecznionym.

Ustawa podatkowa z $1991 \mathrm{r}$. obowiązuje już 26 lat i w odniesieniu do opodatkowania dochodów osiąganych $\mathrm{z}$ tytułu świadczenia pracy, poza marginalnymi zmianami, nie wprowadzała w tym okresie nowych rozwiązań, które byłyby uzasadnione zjawiskami zachodzącymi na rynku pracy w Polsce. Co istotne, ustawodawca podatkowy nie uwzględnił w odpowiedni sposób upowszechnienia się na polskim rynku pracy umów cywilnoprawnych (zwłaszcza umowy-zlecenia oraz umowy o dzieło, oraz w mniejszym zakresie umowy agencyjnej), na podstawie których świadczona jest praca w dłuższych okresach, a nie tylko okazjonalnie.

$\mathrm{W}$ niniejszym artykule, $\mathrm{z}$ uwagi na ograniczone ramy objętościowe, poddano analizie tylko wybrane zagadnienia związane z opodatkowaniem przychodów pracowniczych. Rozważania odnoszą się do koncepcji wprowadzenia zbiorczej kategorii źródeł przychodów nazwanej „pracą najemną”, a także do wewnętrznej struktury źródła przychodów pracowniczych wymienionego w art. 12 ust. 1 pkt 1 u.p.d.f. oraz zryczałtowanych kosztów uzyskania takich przychodów określonych $\mathrm{w}$ art. 22 ust. 2 u.p.d.f. wraz z propozycją zapewnienia mechanizmu ich automatycznej waloryzacji.

W obowiązującej ustawie podatkowej nie zdecydowano się na wprowadzenie unormowań zakładających niższe opodatkowanie dochodów z pracy najemnej wykonywanej w warunkach szczególnych (np. w porze nocnej, w święta i inne dni ustawowo wolne, w warunkach uciążliwych lub szkodliwych dla zdrowia, pracy lub służby związanej z ryzykiem utraty życia, a także wykonywanej ponad obowiązujące pracownika normy czasu pracy). Efektem takich rozwiązań byłoby istotne skomplikowanie zasad opodatkowania dochodów z pracy najemnej, ale należy wyraźnie podkreślić, że praca może być świadczona w różnych, często bardzo odmiennych, warunkach i związana jest z różnymi ryzykami oraz uciążliwościami dla pracownika. Wydaje się, że zasady opodatkowania dochodów z pracy najemnej powinny uwzględniać tę różnorodność warunków i sytuacji, w których taka praca jest wykonywana. Propozycja zmierza do wprowadzenia rozwiązań systemowych polegających na pre-

3 Ustawa z 28 lipca 1983 r. o podatku wyrównawczym, Dz.U. RP nr 42, poz. 188, ze zm.

4 Ustawa z 16 grudnia 1972 r. o podatku dochodowym, Dz.U. 1989, nr 27, poz. 147, ze zm. - w zakresie m.in. opodatkowania dochodów osiąganych z działalności naukowej, artystycznej, literackiej, publicystycznej i oświatowej. 
ferencyjnym opodatkowaniu (np. na zwolnieniu z podatku lub zastosowaniu niższej stawki podatkowej) tej części wynagrodzenia, która pochodzi z pracy wykonywanej w dni świąteczne lub w porze nocnej. Postulat ten odnosi się przede wszystkim do wynagrodzeń pracowników zatrudnionych w zakładach pracy funkcjonujących w ruchu ciągłym (np. wykonujących usługi transportu publicznego) oraz funkcjonariuszy służb odpowiedzialnych za bezpieczeństwo publiczne i zwalczanie skutków zdarzeń losowych (np. Policji, Państwowej Straży Pożarnej, Straży Granicznej). Problemu tego obecnie nie rozwiązuje koncepcja tzw. wynagrodzeń jednostkowych, ponieważ np. zasady opodatkowania części wynagrodzeń, niezależnie od tego, czy zostały one osiągnięte za pracę wykonywaną w porze dziennej, czy w porze nocnej, są identyczne. Podobnie są także opodatkowane wynagrodzenia za godziny nadliczbowe. Uwaga powyższa może również odnosić się do opodatkowania nagród i premii wypłacanych za rzetelne wykonywanie typowych obowiązków pracowniczych, jak i za szczególne poświęcenie i zaangażowanie w warunkach ekstremalnych, np. przy zwalczaniu skutków klęsk żywiołowych, katastrof komunikacyjnych.

Należy ponadto zastanowić się nad przywróceniem mechanizmów zapewniających odpowiednią waloryzację kosztów uzyskania przychodów osiąganych z pracy najemnej, a także limitów zwolnień z opodatkowania określonych składników wynagrodzeń. W opracowaniu zostaną zaproponowane w tym zakresie konkretne rozwiązania, ponieważ taka idea była realizowana w początkowym okresie obowiązywania ustawy podatkowej z $1991 \mathrm{r}$.

Celem artykułu jest przedstawienie analizy i oceny obowiązujących zasad opodatkowania dochodów uzyskiwanych przez osoby fizyczne z pracy najemnej oraz zaproponowanie takich kierunków nowelizacji ustawy podatkowej, które umożliwią dostosowanie reguł opodatkowania do różnych zjawisk towarzyszących wykonywaniu pracy najemnej. W opracowaniu przyjęto autorskie założenie, według którego „wykonywanie pracy w warunkach bardziej uciążliwych lub związanych ze zwiększonym ryzykiem utraty zdrowia albo życia, powinno znajdować odzwierciedlenie $\mathrm{w}$ odpowiednio niższym obciążeniu podatkowym dochodów (lub co najmniej odpowiednich części takich dochodów) uzyskanych przez świadczącego pracę w okolicznościach szczególnych". A contrario identyczne (uniwersalne) reguły, stosowane do opodatkowania dochodów o tej samej wartości, ale uzyskiwanych z pracy świadczonej w różnych warunkach, mogą być oceniane przez opodatkowanych jako niesprawiedliwe i dyskryminujące ich dodatkowy (ponadstandardowy) wysiłek związany z wykonywaniem pracy. Dochodzi bowiem w takiej sytuacji do nadmiernego obciążenia dochodów pracowniczych, których uzyskanie związane było z koniecznością poniesienia dodatkowego wysiłku lub odpowiednio wyższego ryzyka, a więc cena za wykonaną pracę (wynagrodzenie) staje się relatywnie niższa w porównaniu z ceną (wynagrodzeniem) za pracę wykonywaną w sposób standardowy. Wynagrodzenie (dochód) jest ceną uzyskiwaną za pracę i po- 
winno ono być adekwatne do wartości (jakości) pracy, z której świadczeniem są związane określone koszty (wymierne jednoznacznie i wymierne tylko pośrednio), w tym również w postaci dodatkowego wysiłku, zmiany rytmu dobowego (praca zmianowa lub w porze nocnej) albo nawet szybszej utraty zdrowia (praca w warunkach ekstremalnych).

W opracowaniu posłużono się metodą dogmatycznoprawną (przy badaniu materiału normatywnego oraz dorobku doktryny) oraz metodą empiryczną (przy badaniu dorobku judykatury). Ustalono przede wszystkim, że wymienione w art. 10 ust. 1 pkt 1 u.p.d.f. źródło przychodów - określone jako: stosunek służbowy, stosunek pracy, członkostwo w rolniczej spółdzielni produkcyjnej lub innej spółdzielni zajmującej się produkcja rolna, praca nakładcza - jest wewnętrznie zróżnicowane. $Z$ treści tego przepisu nie wynika, aby wszystkie wymienione w nim stosunki prawne traktowane były jako jedno źródło przychodów. Jest to jedynie katalog wielu źródeł przychodów, mających pewne cechy wspólne, takie jak periodyczność świadczeń czy otrzymywanie ich od osoby trzeciej (pracodawcy, który jest jednocześnie płatnikiem obliczającym podatek i pobierającym go od pracobiorcy będącego podatnikiem). Nie oznacza to również identycznego opodatkowania wszystkich źródeł wymienionych w cytowanym przepisie ustawy podatkowej $j^{5}$. Ocenę tę uzasadnia sposób zredagowania treści przepisów związanych $\mathrm{z}$ art. 10 ust. 1 pkt 1 u.p.d.f., a więc $\mathrm{z}$ art. 12 u.p.d.f. oraz art. 22 ust. 2 u.p.d.f., w których określono różne rodzaje przychodów osiąganych $\mathrm{z}$ tzw. pracy najemnej i odmienne limity kosztów uzyskania przychodów w zależności od kryterium geograficznego uwzględniającego miejsce zamieszkania podatnika oraz miejsce usytuowania jego zakładu pracy.

Wewnętrzne zróżnicowanie tego źródła przychodów potwierdzają również ustalenia dokonane po analizie treści art. 21 u.p.d.f., w którym wymieniono zwolnienia przedmiotowe dochodów uzyskiwanych w ramach stosunku służbowego, stosunku pracy, członkostwa $\mathrm{w}$ rolniczej spółdzielni produkcyjnej lub innej spółdzielni zajmującej się produkcją rolną, a także pracy nakładczej. Pomimo tej wewnętrznie zróżnicowanej struktury omawianego źródła przychodów, nie uwzględnia ono niektórych form oraz tytułów prawnych, na podstawie których wykonywana jest w sposób ciągły i w stosunkowo długich okresach tzw. praca najemna. W zakresie opodatkowania podatkiem dochodowym od osób fizycznych podobnie traktowane są umowy o świadczenie określonych usług (zawierane wielokrotnie między tymi samymi podmiotami w krótkich odstępach czasu), do których stosuje się przepisy dotyczące umowy-zlecenia (art. 750 Kodeksu cywilnego ${ }^{6}$ ) albo umowy o dzieło (art. 627 Kodeksu cywilnego) zawierane między pracodawcą i pracobiorcą oraz typowe (kodeksowe)

${ }^{5}$ Wyrok WSA w Warszawie z 26 czerwca 2008 r., sygn. akt III SA/Wa 206/08, LEX nr 477465.

${ }^{6}$ Ustawa z 23 kwietnia 1964 r. - Kodeks cywilny, t.j. Dz.U. 2018, poz. 1025. 
umowy-zlecenia i umowy o dzieło zawierane w celach innych niż wykonywanie określonej pracy. W zakresie obowiązkowego ubezpieczenia społecznego następuje natomiast systematyczne zbliżanie się wymienionych rodzajów umów do pewnego wspólnego standardu.

\section{Postulat ustawowego określenia źródła przychodów „praca najemna”}

Pojęcia „praca najemna” lub „pracownik najemny” nie są stosowane w obowiązującym ustawodawstwie podatkowym. Nie oznacza to jednak, że w ogóle nie są używane w polskim ustawodawstwie. Określenia „praca najemna” oraz "osoba pracująca najemnie” stosowane są w przepisach ustawy z 10 października 2002 r. o minimalnym wynagrodzeniu za pracę (t.j. Dz.U. 2017, poz. 847), ale nie zostały zdefiniowane przez ustawodawcę. Używane są w kontekście ustalania przez Główny Urząd Statystyczny „wskaźnika udziału dochodów z pracy najemnej” oraz „przeciętnej liczby osób na utrzymaniu osoby pracującej najemnie" w ramach badań budżetów gospodarstw domowych. Podobnie w celach statystycznych, realizowanych przez Instytut Ekonomiki Rolnictwa i Gospodarki Żywnościowej w Warszawie, pojęcie „zasoby i nakłady pracy własnej oraz najemnej” występuje w przepisach ustawy ${ }^{7}$, ale bez sprecyzowania jego istotnych cech.

Pojęcie „dochody z pracy najemnej” stosowane jest także w niektórych innych ustawach, ale również nie jest definiowane. Ustawodawca ogranicza się tylko do wyliczenia najbardziej typowych form takich dochodów, np. w postaci pensji, płac oraz innych podobnych wynagrodzeń ${ }^{8}$. Analogicznie określono to pojęcie $\mathrm{w}$ wielu bilateralnych umowach $\mathrm{w}$ sprawach unikania podwójnego opodatkowania ${ }^{9}$ zawartych przez Rzeczpospolitą Polską z poszczególnymi państwami.

7 Zob. art. 3 ustawy z 29 listopada 2000 r. o zbieraniu i wykorzystywaniu danych rachunkowych z gospodarstw rolnych, Dz.U. 2001, nr 3, poz. 20, ze zm.

8 Zob. art. 15 ustawy z 15 grudnia 2016 r. o zasadach unikania podwójnego opodatkowania oraz zapobiegania uchylaniu się od opodatkowania w zakresie podatków od dochodu stosowanych przez Rzeczpospolitą Polską i terytorium, do którego stosuje się prawo podatkowe należące do właściwości Ministra Finansów Tajwanu, Dz.U. poz. 2244.

9 Na przykład w art. 5 umowy z 8 października 2013 r. między Rzecząpospolitą Polską a Baliwatem Guernsey w sprawie unikania podwójnego opodatkowania niektórych kategorii dochodów osób fizycznych, Dz.U. 2014, poz. 1341; art. 14 konwencji z 8 czerwca 2009 r. między Rzecząpospolitą Polską a Republiką Finlandii w sprawie unikania podwójnego opodatkowania i zapobiegania uchylaniu się od opodatkowania w zakresie podatków od dochodu, Dz.U. 2010, nr 37, poz. 205; art. 15 konwencji z 13 lutego 2002 r. między Rzecząpospolitą Polską a Królestwem Niderlandów w sprawie unikania podwójnego opodatkowania i zapobiegania uchylaniu się od opodatkowania w zakresie podatków od dochodu, Dz.U. 2003, nr 216, poz. 2120. 
W przepisach dyrektywy Rady 2003/86/WE z 22 września 2003 r. w sprawie prawa do łączenia rodzin ${ }^{10}$ określenie „praca najemna” stosowane jest jako alternatywa dla pojęcia „praca na własny rachunek”. Pojęć tych jednak nie zdefiniowano w przepisach samej dyrektywy. W dyrektywie Rady z 22 lipca 1977 r. w sprawie kształcenia dzieci pracowników migrujących ${ }^{11}$ użyto określenia „wykonuje lub wykonywał pracę najemną", ale także nie zdefiniowano istoty takiej pracy. W innych aktach prawa unijnego również są stosowane pojęcia „praca najemna” oraz „pracownik najemny”, jednak bez bliższego określenia ich istoty i cech ${ }^{12}$ pozwalających na odróżnienie od pojęcia „praca na własny rachunek”.

Określenia „praca najemna” lub „pracownik najemny” były stosowane również w ustawodawstwie II Rzeczypospolitej ${ }^{13}$, w tym ustawodawstwie podatkowym $^{14}$. W art. 20 ustawy podatkowej z 1920 r. ogólnie określono, że dochodami z uposażeń służbowych, emerytur i z najemnej pracy były wszelkiego rodzaju wynagrodzenia w pieniądzach lub naturze, jakie podatnik uzyskiwał ze stosunku służbowego lub z tytułu najmu pracy łącznie ze wszystkimi dodatkami. Określeń tych jednak nie definiowano.

Konkludując, należy stwierdzić, że ani w okresie II Rzeczypospolitej, ani $\mathrm{w}$ obowiązującym ustawodawstwie polskim oraz $\mathrm{w}$ prawie unijnym nie sformułowano legalnych definicji pojęć „praca najemna” oraz „pracownik najemny”. Ustalenie cech charakterystycznych dla tych pojęć możliwe jest na podstawie dorobku judykatury. Pojęcia te pojawiają się w uzasadnieniach do ponad 2500 wyroków sądowych. Wskazano między innymi, że „praca najemna” nie jest pracą marginalną, a jej wykonywanie następuje w ramach zawartej umo$\mathrm{wy}^{15} \mathrm{i}$ jest podobne do wykonywania zatrudnienia podporządkowanego ${ }^{16}$. Pra-

10 Dz.Urz. UE L 251 z 3 września 2013 r., s. 12, ze zm.

11 Dz.Urz. UE L 199 z 6 sierpnia 1977 r., s. 32.

12 Na przykład art. 12 dyrektywy Rady 2001/55/WE z 20 lipca 2001 r. w sprawie minimalnych standardów przyznawania tymczasowej ochrony na wypadek masowego napływu wysiedleńców oraz środków wspierających równowagę wysiłków między Państwami Członkowskimi związanych z przyjęciem takich osób wraz z jego następstwami (Dz.Urz. UE L 212 z 7 sierpnia 2001 r., s. 12) lub rozporządzenie Parlamentu Europejskiego i Rady (UE) 2016/589 z 13 kwietnia 2016 r. w sprawie europejskiej sieci służb zatrudnienia (EURES), dostępu pracowników do usług w zakresie mobilności i dalszej integracji rynków pracy oraz zmiany rozporządzeń (UE) nr 492/2011 i (UE) nr 1296/2013 (Dz.Urz. UE L 107 z 22 kwietnia 2016 r., s. 1).

${ }_{13}$ Na przykład w ustawie z 28 marca 1933 r. o ubezpieczeniu społecznym, Dz.U. RP nr 51, poz. 396, ze zm.

${ }_{14} \mathrm{Na}$ przykład w ustawie z 16 lipca 1920 r. o państwowym podatku dochodowym i podatku majątkowym (Dz.U. RP nr 82, poz. 550, ze zm.) lub w ustawie z 22 października 1931 r. o kryzysowym dodatku do państwowego podatku dochodowego (Dz.U. RP 1935, nr 45, poz. 311 , ze zm.).

${ }_{15}$ Na przykład postanowienie SN z 16 listopada 2016 r., sygn. akt I UZ 34/16, Legalis nr 1544280 .

16 Na przykład wyrok SN z 9 stycznia 2014 r., sygn. akt I UK 275/13, Legalis nr 1169179. 
ca najemna z reguły jest wykonywana w sposób ciągły (codzienny) i odznacza się realizacją czynności mniej lub bardziej powtarzalnych albo podobnych, bez cech indywidualizujących rezultat, charakterystycznych np. dla umowy o dzie$ł^{17}$. Fakt wykonywania zatrudnienia w niewielkim rozmiarze (w ograniczonym zakresie czasowym) nie oznacza, że nie można mu przypisać charakteru pracy najemnej ${ }^{18}$. Za pracę najemną przysługuje pracownikowi wynagrodzenie wypłacane przez pracodawcę, które najczęściej jest wyrażone w pieniądzu (pensja, płaca itp.), ale może być również wyrażone w naturze ${ }^{19}$.

W piśmiennictwie akcentuje się różne cechy, które powinny charakteryzować pracę najemną. W szczególności konstytutywnymi znamionami stosunku pracy najemnej są: podporządkowanie pracownika oraz wypłata na jego rzecz wynagrodzenia za świadczoną pracę ${ }^{20}$. Pracownik najemny pozostaje w warunkach określonej zależności w relacji do pracodawcy ${ }^{21}$, a wykonywanie tej pracy $\mathrm{z}$ reguły wymaga osobistego zaangażowania się pracownika, w tym jego fizycznej obecności w miejscu świadczenia pracy ${ }^{22}$. Świadczenie pracy najemnej nie wyklucza jednak równoległego wykonywania działalności na własny rachunek, która jest traktowana jako odrębny rodzaj pracy ${ }^{23}$.

Korzystając z dorobku judykatury oraz doktryny, można pod adresem ustawodawcy zgłosić wniosek o sformułowanie legalnych definicji pojęć „praca najemna” oraz "pracownik najemny” dla potrzeb opodatkowania podatkiem dochodowym. Źródło „praca najemna” mogłoby być określoną kategorią zbiorczą, w której zawierałyby się poszczególne tytuły prawne, wymienione w Kodeksie pracy ${ }^{24}$, stosowane w celu nawiązania stosunków pracy (umowa o pracę, powołanie, wybór, mianowanie, spółdzielcza umowa o pracę, umowa o pracę nakładczą). Istotnymi elementami treści definicji pojęcia „praca najemna” powinny być: więź prawna o charakterze dobrowolnym i trwałym, łącząca pracownika najemnego i pracodawcę, obowiązek osobistego wykonywania pracy określonego rodzaju przez tego pracownika pod kierownictwem,

17 Na przykład wyrok SA w Szczecinie z 25 czerwca 2015 r., sygn. akt III AUa 840/14, Legalis nr 1360910.

18 Na przykład wyrok SA w Katowicach 10 grudnia 2013 r., sygn. akt III AUa 90/13, Legalis nr 775716.

19 Na przykład wyrok NSA z 13 maja 2011 r., sygn. akt II FSK 2165/09, Legalis nr 388979.

20 Wspólnotowe prawo gospodarcze, t. I (Swobody rynku wewnętrznego), red. A. Cieśliński, C.H. Beck Warszawa 2008, s. 111-112.

${ }^{21}$ A. Boguska, Konstrukcja delegowania pracowników w celu świadczenia usług na poziomie unijnym i w praktyce prawa polskiego, „Monitor Prawa Pracy” 2016, nr 2, s. 72.

22 B. Kuźniacki, Opodatkowanie zysków z tytułu usług budowlano-montażowych $w$ świetle polsko-norweskiej umowy o unikaniu podwójnego opodatkowania: Pojęcie stałego zakładu usługowego, „Monitor Podatkowy” 2013, nr 3, s. 27.

${ }_{23}$ T. Major, B. Pawłowska, Ubezpieczenia społeczne pracowników delegowanych. Nowe przepisy obowiązujace od 2010 r., „Monitor Prawa Pracy” 2010, nr 6, s. 291.

${ }^{24}$ Ustawa z 26 czerwca 1974 r. - Kodeks pracy, t.j. Dz.U. 2018, poz. 917, ze zm. 
na rzecz i na ryzyko pracodawcy oraz obowiązek pracodawcy zatrudnienia pracownika przy umówionej pracy i wypłacanie mu wynagrodzenia za świadczoną pracę. Powinno to przyczynić się do stworzenia bardziej przejrzystych reguł opodatkowania dochodów osiąganych z tak rozumianego źródła przychodów. Regułami takimi nie powinny natomiast być obejmowane dochody osiągane na podstawie umów cywilnoprawnych, w szczególności na podstawie umowy-zlecenia oraz umowy o dzieło, zgodnie z którymi rezultaty wykonywanych czynności powinny mieć charakter zindywidualizowany.

Wprowadzenie ustawowych definicji pojęć „praca najemna” oraz „pracownik najemny” może skutkować przede wszystkim zmniejszeniem zapotrzebowania na urzędowe interpretacje przepisów prawa podatkowego stosowanych w zakresie wykonywania różnych działalności i zadań, co do których pojawiają się wątpliwości, czy mają one charakter pracy najemnej. Korzystanie w tym zakresie z dotychczasowego dorobku doktryny i judykatury może przyczynić się do poprawy stanu obowiązującego ustawodawstwa, a w konsekwencji poprawy sytuacji pracodawców w relacji do organów podatkowych, jak również w relacji do Państwowej Inspekcji Pracy. Ponadto, zdefiniowanie tych pojęć mogłoby nawiązywać do określonych tradycji ich stosowania w ustawodawstwie z okresu II Rzeczypospolitej, jak i do współczesnych rozwiązań przyjmowanych w aktach prawa unijnego lub aktach międzynarodowego prawa podatkowego (w szczególności umowach bilateralnych dotyczących unikania międzynarodowego podwójnego opodatkowania). Terminy „praca najemna” oraz „dochody z pracy najemnej” stosowane są również w aktach prawnych regulujących różne aspekty statystyki publicznej ${ }^{25}$ lub obowiązkowego ubezpieczenia społecznego ${ }^{26}$.

\section{Ocena konstrukcji ustawowego katalogu przychodów ze stosunków pracy}

$\mathrm{W}$ art. 11 u.p.d.f. zawarta jest norma generalna kształtująca zakres przedmiotowy podatku dochodowego od osób fizycznych. Wynika z niej wyraźnie, że podatkowoprawny stan faktyczny w tym podatku określany jest przez zjawiska

25 Na przykład rozporządzenie Prezesa Rady Ministrów z 28 kwietnia 2010 r. w sprawie określenia wzorów formularzy sprawozdawczych, objaśnień co do sposobu ich wypełniania oraz wzorów kwestionariuszy i ankiet statystycznych stosowanych w badaniach statystycznych ustalonych w programie badań statystycznych statystyki publicznej na rok 2010, Dz.U. nr 106, poz. 676, ze zm.

${ }^{26}$ Na przykład zarządzenie nr 50 Prezesa Kasy Rolniczego Ubezpieczenia Społecznego z 18 listopada 2016 r. w sprawie wprowadzenia instrukcji techniczno-biurowej w zakresie wykonywania zadań dotyczących podlegania ubezpieczeniu społecznemu rolników i ubezpieczeniu zdrowotnemu oraz rozliczeń z tytułu składek na te ubezpieczenia, Dz.Urz. KRUS 2016, poz. 52. 
faktyczne lub prawne mające swój realny wymiar. Przychody podatkowe stanowią w szczególności wartości otrzymanych świadczeń w naturze i innych nieodpłatnych świadczeń. Można przyjąć, że przepisem szczególnym w stosunku do tej regulacji jest norma prawna art. 12 ust. 1 u.p.d.f., odnosząca się do przychodów uzyskiwanych z szeroko rozumianego stosunku służbowego i stosunku pracy ${ }^{27}$.

$\mathrm{W}$ art. 12 ust. 1 u.p.d.f. wymieniono katalog tzw. przychodów pracowniczych, tzn. przychodów, które są możliwe do uzyskania przez osobę pozostającą w stosunku służbowym, stosunku pracy, pracy nakładczej oraz spółdzielczym stosunku pracy. W konstrukcji tego katalogu przychodów wykorzystano dwa kryteria, tzn. ogólne (uniwersalne) zakwalifikowanie przychodów do omawianego źródła oraz szczegółowe wyliczenie najpowszechniej występujących (standardowych) rodzajów przychodów pracowniczych. Według pierwszego kryterium za takie przychody uważa się wszelkiego rodzaju wypłaty pieniężne oraz wartość pieniężną świadczeń w naturze bądź ich ekwiwalenty, bez względu na źródło finansowania tych wypłat i świadczeń. Według drugiego kryterium przychodami takimi są w szczególności: wynagrodzenia zasadnicze, wynagrodzenia za godziny nadliczbowe, różnego rodzaju dodatki, nagrody, ekwiwalenty za niewykorzystany urlop i wszelkie inne kwoty niezależnie od tego, czy ich wysokość została z góry ustalona, a ponadto świadczenia pieniężne ponoszone za pracownika, jak również wartość innych nieodpłatnych świadczeń lub świadczeń częściowo odpłatnych.

Katalog skonstruowany na podstawie drugiego kryterium ma charakter otwarty i umożliwia poddanie opodatkowaniu podatkiem dochodowym również takich rodzajów przychodów pracowniczych, których wprost nie wymieniono w cytowanym przepisie ustawy podatkowej. W efekcie przychodem ze stosunku pracy i stosunków pokrewnych mogą być wszelkiego rodzaju wypłaty i świadczenia skutkujące u podatnika powstaniem przysporzenia majątkowego, mające swoje źródło w łączącym pracownika z pracodawcą stosunku pracy lub stosunku pokrewnym. Należy jednak podkreślić, że rodzaje przychodów, których nie wymieniono wprost $\mathrm{w}$ tym przepisie, powinny mieścić się $\mathrm{w}$ granicach wyznaczonych przez pierwsze kryterium. Prowadzi to do wniosku, że każda korzyść uzyskana w związku z wykonywaniem pracy w ramach stosunków wymienionych $\mathrm{w}$ tym przepisie podlega opodatkowaniu podatkiem dochodowym, chyba że na podstawie wyraźnego stwierdzenia ustawodawcy została zwolniona $\mathrm{z}$ opodatkowania ${ }^{28}$.

27 R. Mastalski, Glosa do uchwaty NSA $z$ dnia 24 maja 2010 r., II FPS 1/10, „Orzecznictwo Sądów Powszechnych" 2010, nr 12, poz. 121.

28 D. Strzelec, Komentarz do art. 12 [w:] Komentarz do ustawy o podatku dochodowym od osób fizycznych, red. W. Nykiel, A. Mariański, ODDK, Gdańsk 2015, s. 191. 
Kryteria przedmiotowe określone w art. 12 ust. 1 u.p.d.f. powinny być stosowane łącznie $\mathrm{z}$ kryterium podmiotowym sformułowanym w art. 12 ust. 4 u.p.d.f., zgodnie z którym za pracownika w rozumieniu tej ustawy uważa się osobę pozostającą w stosunku służbowym, stosunku pracy, stosunku pracy nakładczej lub spółdzielczym stosunku pracy. Oznacza to, że kryterium decydującym o tym, czy dane świadczenie jest świadczeniem pracowniczym, nie jest źródło finansowania wydatku przez pracodawcę, ale okoliczność, czy świadczenie to może otrzymać wyłącznie pracownik czy też inna osoba niezwiązana z pracodawcą stosunkiem pracy i czy między świadczeniem a stosunkiem pracy istnieje związek faktyczny i prawny ${ }^{29}$. Z postanowień analizowanych przepisów ustawy podatkowej wynika jednoznacznie, że przychód pracowniczy powstaje tylko wtedy, gdy pracownik uzyskuje realne przysporzenie majątkowe, którego wartość jest ściśle określona ${ }^{30}$. Warunkiem powstania zobowiązania podatkowego jest istnienie kryterium pozwalającego na zindywidualizowanie i przypisanie konkretnej osobie wysokości osiągniętego przez tę osobę przychodu ${ }^{31}$.

Wszystkie wymienione w art. 12 u.p.d.f. tytuły są ex definitione przychodami ze stosunku pracy, a więc tym, co otrzymuje pracownik od pracodawcy za świadczoną pracę. W świetle tej definicji za przychody ze stosunku pracy należy uznać wartości otrzymywane przez pracownika od zakładu pracy, będące ekwiwalentem wartości wykonanej pracy, mające podstawę prawną. Charakterystyczną cechą przychodów ze stosunku pracy jest to, że otrzymywane są one przez pracownika od pracodawcy - z jego zasobów finansowych (a co najmniej zasobów, które są w dyspozycji pracodawcy) i w związku ze świadczeniem pracy jako ekwiwalent wysiłku pracowniczego ${ }^{32}$.

Sposób sformułowania w art. 12 ust. 1 i 4 u.p.d.f. kryteriów kwalifikowania przychodów do kategorii przychodów pracowniczych sprawia, że w tym zakresie pojawiają się liczne wątpliwości dotyczące opodatkowania danego rodzaju przychodu lub wyłączenia go z opodatkowania podatkiem dochodowym od osób fizycznych. Źródłem tych wątpliwości jest przede wszystkim otwarty katalog typowych przychodów pracowniczych. O jego statusie prawnym jako katalogu otwartym przesądza użycie w treści art. 12 ust. 1 u.p.d.f. zwrotu „W szczególności”, który sprawia, że zastosowane po tym zwrocie wyliczenie jest jedynie przykładowe i ograniczone do najbardziej typowych przychodów pracowniczych. Kryterium ogólne, w którego konstrukcji zastosowano zwrot „uważa się wszelkiego rodzaju...” wzmacnia otwarty charakter tego katalogu przychodów, a ponadto przyczynia się do wzrostu poczucia określonej niesta-

29 Wyrok WSA w Gdańsku z 21 czerwca 2017 r., sygn. akt I SA/Gd 461/17, Legalis nr 1650146; wyrok NSA z 28 czerwca 2016 r., sygn. akt II FSK 1490/14, Legalis nr 1486253.

30 Wyrok NSA z 23 kwietnia 2015 r., sygn. akt II FSK 1157/13, Legalis nr 1248699.

31 Wyrok NSA z 3 grudnia 2014 r., sygn. akt II FSK 2984/14, Legalis nr 1161730.

32 B. Brzeziński, Glosa do wyroku NSA z dnia 17 maja 2013 r., II FSK 1812/11, „Orzecznictwo Sądów Powszechnych” 2014, nr 1, poz. 10. 
bilności reguł opodatkowania przychodów pracowniczych, ponieważ ustawowe stwierdzenie „uważa się" może być kojarzone z określoną uznaniowością występującą po stronie organów podatkowych zmierzających do maksymalizacji wpływów podatkowych.

W związku z tym często dochodzi do sporów między podatnikami i organami podatkowymi, rozstrzyganych dopiero przez sądy. Uwaga krytyczna nie odnosi się w jednakowym zakresie do wszystkich kategorii przychodów, które można wyodrębnić w wyniku analizy treści art. 12 u.p.d.f. Najmniej problemów pojawia się w odniesieniu do typowych wypłat pieniężnych na rzecz pracownika. Jednak pozostałe trzy kategorie przychodów (wartość świadczeń w naturze bądź ich ekwiwalenty; wartość świadczeń pieniężnych ponoszonych za pracownika; wartość innych nieodpłatnych lub częściowo odpłatnych świadczeń) $\mathrm{w}$ różnych okresach były przedmiotem wielu interpretacji urzędowych oraz orzeczeń sądów. Swoistą przyczyną tych problemów może być odmienny charakter zdarzeń powodujących powstanie przychodu po stronie pracownika. Świadczenia w naturze i inne nieodpłatne świadczenia tylko wtedy spowodują powstanie po stronie pracownika przychodu, gdy zostaną przez niego otrzymane ${ }^{33}$. Z kolei do zaistnienia przychodu w postaci pieniędzy i wartości pieniężnych wystarczy jedynie ich postawienie do dyspozycji podatnika ${ }^{34}$, a więc w tym wypadku uzasadnienie ich poddania opodatkowaniu jest względnie proste.

W odniesieniu do wypłat pieniężnych problemy interpretacyjne dotyczyły między innymi opodatkowania odpraw przewidzianych w programach (lub w indywidualnych porozumieniach) dobrowolnych odejść pracowników ${ }^{35}$ (generalnie przyjmowano, że nie były one objęte zwolnieniem $z$ art. 21 ust. 1 pkt 3 u.p.d.f. i powinny być traktowane jako przychód pracownika podlegający opodatkowaniu). Określone wątpliwości powstawały także w odniesieniu do opodatkowania tzw. napiwków wypłacanych pracownikom np. kasyn lub restauracji. Ich opodatkowanie jest możliwe wtedy, gdy środki w postaci napiwków są adresowane imiennie do określonego pracownika lub grupy pracowników, trafiają do pracodawcy albo też pracodawca zbiera takie środki, a następnie przekazuje je pracownikom, którzy dokonują ich podziału między siebie. Powinny zatem być kwalifikowane jako przychody ze stosunku pracy i podlegać

33 J. Pustuł, Imprezy integracyjne a przychód z nieodpłatnych świadczeń, „Przegląd Podatkowy" 2013, nr 9, s. 37.

${ }_{34}$ Wyrok WSA we Wrocławiu z 13 sierpnia 2013 r., sygn. akt I SA/Wr 788/13, LEX nr 1391402; wyrok WSA w Szczecinie z 20 stycznia 2010 r., sygn. akt I SA/Sz 862/09, LEX nr 580538.

35 Wyrok WSA w Poznaniu z 8 czerwca 2017 r., sygn. akt I SA/Po 1638/16, Legalis nr 1612044; wyrok WSA w Warszawie z 6 kwietnia 2017 r., sygn. akt III SA/Wa 1051/16, Legalis nr 1603289; wyrok WSA w Białymstoku z 22 lutego 2017 r., sygn. akt I SA/Bk 1061/16, Legalis nr 1596391. 
opodatkowaniu łącznie $\mathrm{z}$ wynagrodzeniem za pracę ${ }^{36}$. Jeżeli pracownik bezpośrednio od klientów (bez pośrednictwa pracodawcy) otrzymuje napiwki, to wówczas ich wypłaty nie dokonuje pracodawca i wartości tych napiwków nie można zaliczyć do przychodów ze stosunku pracy. Napiwki te stanowią wówczas przychód z innych źródeł w rozumieniu art. 20 ust. 1 u.p.d.f. ${ }^{37}$.

Nie powinny pojawiać się wątpliwości w procesie identyfikacji i ustalania wartości „świadczeń pieniężnych ponoszonych przez pracodawcę za pracownika”. Problem powstawał między innymi wtedy, gdy pracodawca dokonywał zakupu usług profilaktyczno-medycznych dla pracowników obejmujących jednocześnie wykonanie badań wynikających z przepisów Kodeksu pracy oraz badań dodatkowych. $\mathrm{W}$ takim wypadku opodatkowaniu powinna podlegać tylko wartość pieniężna tej części opłaconej za pracownika składki, która przypada na dodatkowe badania ${ }^{38}$. Zapłata składki przez pracodawcę za pracownika stanowi wymierną korzyść dla tego ostatniego z tytułu zawarcia na jego rzecz umowy ubezpieczenia, która powinna być traktowana jako przychód pracownika. Jeżeli pracodawca zbiorowo ubezpiecza pracowników i wykupuje polisę ubezpieczeniową dla wielu z nich, a opłata za tę polisę jest zryczałtowana, niezbędne jest wykazanie, że możliwa jest identyfikacja ceny konkretnej usługi ponoszonej na rzecz konkretnego pracownika ${ }^{39}$, ponieważ przepisy ustawy podatkowej nie przewidują doliczenia do dochodu pracownika wartości świadczeń ponoszonych przez pracodawcę na rzecz pracownika w sytuacji, gdy nie można określić wartości świadczenia z przyczyn faktycznych lub prawnych ${ }^{40}$.

Trudny do zaakceptowania jest pogląd sądu, który uznał, że opłata zryczałtowana za usługę wykupioną na rzecz grupy pracowników może być podzielona przez liczbę uprawnionych pracowników, niezależnie od tego z jakiej ilości świadczeń indywidualny pracownik rzeczywiście skorzystał. Zdaniem sądu fakt dokonywania opłat $\mathrm{w}$ formie zryczałtowanej nie uniemożliwia identyfikacji wartości świadczenia przypadającej na konkretną osobę ${ }^{41}$. W takim wypadku nie jest możliwe ustalenie konkretnej kwoty przychodu powstającego

${ }^{36}$ Wyrok NSA z 4 kwietnia 2012 r., sygn. akt II FSK 1747/10, „Przegląd Orzecznictwa Podatkowego" 2013, nr 1, s. 68.

37 P. Borszowski, Glosa do wyroku NSA z dnia 14 listopada 2003 r., I SA/Łd 1493/2002, "Przegląd Orzecznictwa Podatkowego" 2005, nr 2, s. 124; wyrok WSA w Warszawie z 8 marca 2010 r., sygn. akt III SA/Wa 1763/09, Legalis nr 228467.

${ }_{38}$ Wyrok WSA w Warszawie z 18 stycznia 2012 r., sygn. akt III SA/Wa 2945/11, LEX nr 1139472.

39 Wyrok WSA w Warszawie z 10 grudnia 2007 r., sygn. akt III SA/Wa 1302/07, LEX nr 329095.

${ }^{40}$ Wyrok WSA w Warszawie z 16 lutego 2010 r., sygn. akt III SA/Wa 1055/09, LEX nr 575068.

${ }^{41}$ Wyrok WSA w Poznaniu z 19 stycznia 2010 r., sygn. akt I SA/Po 836/09, LEX nr 559531. 
w odniesieniu do konkretnego pracownika ${ }^{42}$. Sposób rozumowania sądu zbliża się do idei „kontyngentu podatkowego”, tzn. obciążenia podatkowego nakładanego na określoną zbiorowość, która może (ale nie jest zobowiązana) zadecydować o ewentualnym rozłożeniu ciężarów na poszczególnych członków tej zbiorowości, przy czym rozkład tych obciążeń nie musi być równy. Podatek dochodowy od osób fizycznych jest przede wszystkim podatkiem indywidualnym, obejmującym rzeczywiście osiągnięte przychody przez konkretnego podatnika, a więc takie potraktowanie przez sąd świadczenia pieniężnego poniesionego przez pracodawcę za określoną grupę pracowników jest sprzeczne z ogólną koncepcją tego podatku.

W dorobku orzeczniczym sądów zwracają uwagę przejrzyście ukształtowane kryteria kwalifikowania do ewentualnego opodatkowania „świadczeń w naturze" oraz tzw. innych nieodpłatnych świadczeń. Warunkiem uznania, że dane świadczenie w naturze stanowi nieodpłatne świadczenie, jest faktyczne otrzymanie świadczenia przez pracownika, a nie jedynie możliwość skorzystania z danego świadczenia. Zatem sama możliwość skorzystania ze świadczenia (np. dowozu do pracy) nie może być uznana za skonkretyzowaną i zindywidualizowaną, wymierną korzyść majątkową ${ }^{43}$. Trafnie uznano, że za przychód pracownika mogą być uznane świadczenia, które: zostały spełnione za zgodą pracownika (skorzystał $\mathrm{z}$ nich w pełni dobrowolnie); zostały spełnione w jego interesie (a nie w interesie pracodawcy) i przyniosły mu korzyść w postaci powiększenia aktywów lub uniknięcia wydatku, który musiałby ponieść; stanowią korzyść wymierną i przypisaną indywidualnemu pracownikowi (nie jest ona dostępna w sposób ogólny dla wszystkich podmiotów) ${ }^{44}$. Istotą podatku dochodowego jest opodatkowanie skonkretyzowanego przysporzenia, a nie potencjalnej możliwości jego uzyskania. Reguła ta dotyczy zwłaszcza świadczeń w naturze i innych nieodpłatnych świadczeń, w odniesieniu do których ustawodawca posłużył się jednoznacznym zwrotem „otrzymane" ${ }^{\text {"45. Wniosek }}$ taki wynika z nakazu łącznej analizy treści przepisu art. 12 u.p.d.f. oraz art. 11 ust. 1 u.p.d.f., w którym zamieszczono ogólne pojęcie przychodu. Charakterystyczną cechą nieodpłatnych świadczeń jest osiągnięcie nieodpłatnego przysporzenia majątku, mające konkretny wymiar finansowy ${ }^{46}$. Jeżeli nie jest możliwe ustalenie, czy pracownik faktycznie i w jakiej wysokości korzystał z nieodpłatnych świadczeń, lub nie można przyporządkować świadczenia do

42 A. Mariański, D. Strzelec, Glosa do uchwały NSA $z$ dnia 24 maja 2010 r., II FPS 1/10, „Przegląd Podatkowy” 2010, nr 9, s. 44.

${ }^{43}$ Wyrok NSA z 11 grudnia 2014 r., sygn. akt II FSK 3275/14, LEX nr 1595926.

${ }^{44}$ Wyrok TK z 8 lipca 2014 r., sygn. akt K 7/13, Dz.U. poz. 947; wyrok NSA z 18 stycznia 2015 r., sygn. akt II FSK 3401/14, LEX nr 1566846.

${ }^{45}$ Postanowienie NSA z 13 października 2013 r., sygn. akt II FPS 7/14, LEX nr 1536815.

46 Wyrok WSA w Rzeszowie z 27 marca 2014 r., sygn. akt I SA/Rz 1154/13, LEX nr 1452391. 
konkretnego przychodu przewidzianego w przepisach podatkowych i wyliczyć przychodu, to w rezultacie nie można włączyć tych świadczeń do przychodów konkretnego pracownika ${ }^{47}$.

Dominuje w orzecznictwie pogląd, że nie są świadczeniami spełnianymi $\mathrm{w}$ interesie pracownika świadczenia polegające na pokrywaniu przez pracodawcę kosztów noclegów pracownika w trasie, opłat parkingowych, kosztów posiłków spożywanych w czasie spotkania służbowego z klientem, opłat za przejazd autostradą. Są to świadczenia realizowane $\mathrm{w}$ interesie pracodawcy i nie przynoszą one pracownikowi korzyści w postaci powiększenia aktywów lub uniknięcia wydatków, które musiałby on samodzielnie ponieść. Zapewnienie pracownikom wskazanych powyżej usług leży bowiem wyłącznie w interesie pracodawcy, a nie pracowników, którzy swoje potrzeby, np. mieszkaniowe, zaspokajają w innym miejscu i w inny sposób, oraz którzy - gdyby nie konieczność wywiązania się z obowiązków wynikających z umowy o pracę - nie mieliby powodu do ponoszenia kosztu takich noclegów $w^{48}$.

Dowożenie natomiast pracownika z miejsca zamieszkania do pracy może stanowić co do zasady przychód ze stosunku pracy w postaci nieodpłatnego świadczenia, bowiem oznacza dla pracownika przysporzenie w postaci zaoszczędzenia wydatku. Zasadniczym warunkiem uznania go za takie nieodpłatne świadczenie będzie dysponowanie zgodą pracownika na korzystanie $\mathrm{z}$ dojazdów oraz faktyczne skorzystanie z tego świadczenia. Nie jest natomiast wystarczające samo zapewnienie pracownikowi możliwości korzystania z dojazdów do pracy na koszt pracodawcy. Nadto warunkiem uznania tego świadczenia za przychód poszczególnych pracowników będzie możliwość przypisania im wymiernej skonkretyzowanej korzyści z tego tytułu ${ }^{49}$.

Ze względu na otwarty i rozwijający się katalog świadczeń oferowanych przez pracodawców na rzecz pracowników nie jest możliwe enumeratywne wyliczenie w ustawie podatkowej wszystkich nieodpłatnych świadczeń, które zgodnie z zasadą powszechności przedmiotowej podatku dochodowego powinny być przez ustawodawcę uwzględnione. Korzystając jednak z bogatego dorobku orzeczniczego sądów, ustawodawca powinien podjąć próbę skonstruowania uniwersalnej definicji takiego „nieodpłatnego świadczenia” opartej na wyżej wymienionych cechach wskazanych w przywołanym wcześniej wyroku Trybunału Konstytucyjnego z 8 lipca 2014 r. Przyczyniłoby się to do ograniczenia pewnej uznaniowości w kwalifikowaniu określonych świadczeń do tej kategorii i związanych z tą uznaniowością problemów interpretacyjnych.

${ }^{47}$ M. Bosak, P. Majka, Charakter prawny pracowniczych świadczeń nieodpłatnych $w$ świetle regulacji prawa pracy oraz prawa podatkowego, „Studia z Zakresu Prawa Pracy i Polityki Społecznej" 2013, nr 1, s. 349.

48 Wyrok NSA z 20 kwietnia 2017 r., sygn. akt II FSK 760/15, Legalis nr 1649439.

49 Wyrok NSA z 17 maja 2017 r., sygn. akt II FSK 1132/15, Legalis nr 1629506. 
Podobne uwagi dotyczą pojęcia „świadczenia w naturze lub ich ekwiwalenty”. Kryteria opisowe, wykorzystane przy definiowaniu pojęcia „świadczenia nieodpłatne", mogłyby być wykorzystane przy formułowaniu ustawowej definicji świadczeń w naturze, a w szczególności: ich spełnienie za zgodą pracownika i w jego interesie, a także pojawienie się wymiernej i zindywidualizowanej korzyści po stronie pracownika.

Sformułowanie opisowych definicji „nieodpłatnego lub częściowo odpłatnego świadczenia pracodawcy na rzecz pracownika” oraz „świadczenia w naturze" byłoby ważnym osiągnięciem w procesie wyznaczania precyzyjnych granic przedmiotowych podatku dochodowego od osób fizycznych. Wyżej wymienione kategorie przychodów pracowniczych zawierają się w przedmiocie podatku dochodowego. W rezultacie tych zmian ustawodawca podatkowy istotnie zbliżyłby się do standardu konstytucyjnego określonego w art. 217 Konstytucji RP ${ }^{50}$, zgodnie z którym „określanie przedmiotów opodatkowania następuje w drodze ustawy”. Użyty w treści art. 217 Konstytucji RP zwrot „przedmiot podatku” powinien być rozumiany jako nakaz określenia $\mathrm{w}$ ustawie podatkowej rzeczy i zjawisk, które przez nawiązanie do źródła opodatkowania wskazują na zdolność ekonomiczną do poniesienia podatku w taki sposób, aby przejrzysta i przewidywalna była wynikająca stąd podstawa odniesienia do stawek podatkowych ${ }^{51}$. Ewentualne unormowanie ustawowe „nieodpłatnych świadczeń” mogłoby odznaczać się wtedy cechami kompletności, precyzji i jednoznaczności, które w piśmiennictwie traktowane są jako standardy poprawnej legislacji podatkowej ${ }^{52}$.

\section{Problem waloryzacji limitów kosztów uzyskania przychodów pracowniczych}

W odniesieniu do przychodów pracowniczych zastosowano uproszczoną formułę kosztów uzyskania przychodów. Przybiera ona postać miesięcznych ryczałtów kwotowych ${ }^{53}$, z jednoczesnym ustaleniem limitów rocznych, których wysokość została uzależniona od liczby stosunków pracy nawiązanych przez pracownika oraz relacji między jego miejscem zamieszkania a miejscem wykonywania pracy. Od dnia 1 stycznia 2007 r. limity kwotowe zryczałtowanych kosztów uzyskania przychodów pracowniczych nie były podwyższane. W tym okresie minimalne wynagrodzenie było systematycznie podwyższane. W efek-

${ }^{50}$ Konstytucja Rzeczypospolitej Polskiej z 2 kwietnia 1997 r., Dz.U. nr 78, poz. 483, ze zm.

${ }^{51}$ T. Dębowska-Romanowska, Prawo finansowe. Część konstytucyjna wraz z częścia ogólną, C.H. Beck Warszawa 2010, s. 154.

${ }_{52}$ M. Bartoszewicz, J. Zakolska, Glosa do wyroku sqdu okręgowego z dnia 20 maja 2003 r., IV Ka 893/02, „Przegląd Legislacyjny” 2003, nr 5, s. 116.

${ }_{53}$ W. Nykiel, A. Mariański, M. Wilk, Komentarz do art. 22 [w:] Komentarz do ustawy o podatku dochodowym od osób fizycznych, red. W. Nykiel, A. Mariański, ODDK, Gdańsk 2015, s. 495. 
cie relacja tych limitów kwotowych do kwoty minimalnego wynagrodzenia ulegała erozji w każdym kolejnym roku podatkowym. Można to wykazać, zestawiając miesięczny oraz roczny limit kwotowy kosztów uzyskania przychodów pracowniczych podatnika uzyskującego przychody z tytułu jednego stosunku służbowego (odpowiednio: stosunku pracy, spółdzielczego stosunku pracy lub pracy nakładczej) z kwotami minimalnego wynagrodzenia.

Tabela 1. Relacja zryczałtowanych kosztów uzyskania przychodów pracowniczych do kwoty minimalnego wynagrodzenia w latach 2007-2018

\begin{tabular}{|l|c|c|c|c|c|}
\hline Rok & $\begin{array}{c}\text { Limit miesięczny } \\
\text { (w zł) }\end{array}$ & $\begin{array}{c}\text { Limit roczny } \\
\mathbf{( w ~ z ł )}\end{array}$ & $\begin{array}{c}\text { Minimalne } \\
\text { wynagrodzenie* } \\
\text { (w zł) }\end{array}$ & $\begin{array}{c}\text { Udział } \\
\text { procentowy limitu } \\
\text { miesięcznego } \\
\text { w wynagrodzeniu } \\
\text { minimalnym }\end{array}$ & $\begin{array}{c}\text { Udział procentowy } \\
\text { limitu rocznego } \\
\text { w wynagrodzeniu } \\
\text { minimalnym }\end{array}$ \\
\hline 2007 & 111,25 & 1335,00 & 936,00 & 11,89 & 142,63 \\
\hline 2008 & 111,25 & 1335,00 & 1126,00 & 9,88 & 118,56 \\
\hline 2009 & 111,25 & 1335,00 & 1276,00 & 8,72 & 104,62 \\
\hline 2010 & 111,25 & 1335,00 & 1317,00 & 8,45 & 101,37 \\
\hline 2011 & 111,25 & 1335,00 & 1386,00 & 8,03 & 96,32 \\
\hline 2012 & 111,25 & 1335,00 & 1500,00 & 7,42 & 89,00 \\
\hline 2013 & 111,25 & 1335,00 & 1600,00 & 6,95 & 83,44 \\
\hline 2014 & 111,25 & 1335,00 & 1680,00 & 6,62 & 79,46 \\
\hline 2015 & 111,25 & 1335,00 & 1750,00 & 6,36 & 76,29 \\
\hline 2016 & 111,25 & 1335,00 & 1850,00 & 6,01 & 72,16 \\
\hline 2017 & 111,25 & 1335,00 & 2000,00 & 5,56 & 66,75 \\
\hline 2018 & 111,25 & 1335,00 & 2100,00 & 5,30 & 63,57 \\
\hline
\end{tabular}

* Kwoty podano zgodnie z obowiązującymi w kolejnych latach rozporządzeniami Rady Ministrów, a w latach 2009 i 2010 obwieszczeniami Prezesa Rady Ministrów w sprawie wysokości minimalnego wynagrodzenia za pracę.

$\mathrm{Z}$ danych zamieszczonych w tabeli 1 wynika, że udział miesięcznego oraz rocznego limitu kosztów uzyskania przychodów pracowniczych w roku 2018 w porównaniu z rokiem 2007 zmniejszył się ponad dwukrotnie. Jeżeli zostałaby zachowana w $2018 \mathrm{r}$. identyczna relacja między limitami kwotowymi przychodów oraz wynagrodzeniem minimalnym, to limit miesięczny powinien wynosić 249,69 zl, natomiast limit roczny 2996,28 zł. Zaniechanie waloryzacji limitów kwotowych de facto wpływa na wzrost obciążenia podatkowego, który jest efektem nominalnego wzrostu wynagrodzeń pracowniczych oraz zjawiska inflacji. W latach 2007-2016 wskaźnik inflacji, według informacji GUS wynosił: w 2007 r. 2,5\%; w 2008 r. 4,2\%; w 2009 r. 3,5\%; w 2010 r. 2,6\%; w 2011 r. 4,3\%; w 2012 r. 3,7\%; w 2013 r. 0,9\%; w 2014 r. 0,0\%. W latach 2015-2016 w Polsce miała miejsce deflacja odpowiednio w wysokości $0,9 \%$ oraz $0,6 \%$. W 2017 r. (na koniec września wyniosła 2,2\%). Skumulowany wskaźnik inflacji (po uwzględnieniu deflacji w latach 2015-2016) wynosił zatem 22,4\%. Uzasadnione $\mathrm{z}$ tego powodu było okresowe waloryzowanie limitów kwoto- 
wych kosztów uzyskania przychodów pracowniczych. W porównaniu z $2007 \mathrm{r}$. limity kwotowe powinny zatem wzrosnąć o 22,4\% (np. z poziomu 111,25 zł do 136,17 zł oraz odpowiednio z poziomu 1335 zł do 1634,04 zł).

Przywrócenie mechanizmu automatycznej waloryzacji limitów kwotowych kosztów uzyskania przychodów pracowniczych jest konieczne $\mathrm{z}$ uwagi na potrzebę ochrony realnej wartości dochodów uzyskiwanych z pracy najemnej. Mechanizm taki był już stosowany od 1 stycznia 1992 r. do 31 grudnia $2003 \mathrm{r}$. W tym okresie koszty uzyskania przychodów pracowniczych określano w miesięcznej wysokości $0,25 \%$ kwoty stanowiącej górną granicę pierwszego przedziału skali ustalonej w art. 27 ust. 1 u.p.d.f. Od 1 stycznia 1995 r. powyższą regułę uzupełniono i podatnik uzyskujący przychody równocześnie z kilku zakładów pracy mógł stosować koszty uzyskania za rok podatkowy łącznie do $4,5 \%$ wymienionej kwoty. Mechanizm ten był powiązany z innym mechanizmem waloryzacyjnym określonym $\mathrm{w}$ art. 27 ust. 3 u.p.d.f., według którego przedziały dochodu podlegającego opodatkowaniu podatkiem, określone w skali podatkowej w art. 27 ust. 1 u.p.d.f., oraz kwota zmniejszająca podatek lub zaliczkę podatkową (decydująca o wysokości kwoty dochodu wolnego od opodatkowania) podlegały w każdym roku podwyższeniu w stopniu odpowiadającym wskaźnikowi wzrostu przeciętnego wynagrodzenia miesięcznego w gospodarce narodowej w okresie trzech kwartałów w roku poprzedzającym rok podatkowy w stosunku do analogicznego okresu roku ubiegłego. Od 1 stycznia 2002 r. mechanizm ten został częściowo zmodyfikowany i zgodnie z art. 27 ust. 4 i 5 u.p.d.f. waloryzację kwoty zmniejszającej podatek oraz kwotowych progów skali podatkowej powiązano ze wzrostem cen towarów i usług konsumpcyjnych w okresie pierwszych trzech kwartałów w roku poprzedzającym rok podatkowy. Z dniem 1 stycznia 2004 r. uchylono wyżej wskazane mechanizmy waloryzacyjne, rezygnując z obiektywnych wskaźników ekonomicznych na rzecz autonomicznej decyzji ustawodawcy ${ }^{54}$. Z perspektywy doświadczeń ponad 14-letniego okresu braku okresowej waloryzacji limitów kwotowych kosztów uzyskania przychodów pracowniczych, a także progów skali podatkowej, można stwierdzić, że rezygnacja z mechanizmu automatycznej waloryzacji tych limitów kwotowych była decyzją negatywnie oddziałującą na opodatkowanie dochodów pracowniczych.

\section{Podsumowanie}

Analiza wybranych zagadnień dotyczących obowiązujących zasad opodatkowania przychodów osiąganych ze stosunków pracy i stosunków pokrewnych pozwala na sformułowanie ogólnych ocen, ale skłania również do zgłoszenia

${ }^{54}$ Uzasadnienie projektu ustawy o zmianie ustawy o podatku dochodowym od osób fizycznych oraz niektórych innych ustaw, druk sejmowy nr 1853/ IV kad. 
wniosków de lege ferenda. Ponad 26-letni okres obowiązywania ustawy o podatku dochodowym od osób fizycznych w odniesieniu do opodatkowania tzw. przychodów pracowniczych trudno jednoznacznie ocenić pozytywnie lub negatywnie. Istotnym walorem dotychczasowych unormowań jest ich względna stabilność, co z kolei pozytywnie wpłynęło na upowszechnienie wśród podatników (oraz wśród płatników) wiedzy o podstawowych regułach opodatkowania przychodów pracowniczych. Ważnym osiągnięciem jest również unifikacja zasad opodatkowania takich dochodó $\mathrm{w}^{55} \mathrm{w}$ ramach jednej daniny publicznej i rezygnacja ze stosowanego przed rokiem 1992 sektorowego zróżnicowania tych zasad w postaci kilku odmiennych, pod względem konstrukcyjnym, podatków (np. podatku od wynagrodzeń lub podatku od płac).

Dorobek doktryny prawa podatkowego oraz judykatury, a także lektura wielu urzędowych interpretacji przepisów ustawy podatkowej wskazują na potrzebę podjęcia działań odnoszących się do opodatkowania przychodów pracowniczych. Działania takie mogą stać się elementem składowym większej reformy opodatkowania dochodów w Polsce, w której zgłaszany jest również postulat nowej klasyfikacji źródeł przychodów. Jednym z takich źródeł byłyby przychody z aktywności zawodowej i obywatelskiej obejmujące między innymi przychody z pracy najemnej osiągane z różnych stosunków prawnych łączących pracownika z pracodawcą ${ }^{56}$.

Efektem przeprowadzonych analiz są następujące rekomendacje i wnioski de lege ferenda:

- wprowadzenie zbiorczej kategorii o nazwie „praca najemna”, opartej na opisowych kryteriach wspólnych dla różnych stosunków prawnych, w ramach których osobiście świadczona jest praca za wynagrodzeniem, w warunkach podporządkowania i na cudzy rachunek (rodzaje stosunków prawnych łączących pracownika najemnego z pracodawcą $\mathrm{w}$ tej kategorii powinny być wyczerpująco wyliczone),

- z uwagi na istotne rozbieżności interpretacyjne niektórych rodzajów przychodów ze stosunków pracy (w szczególności nieodpłatnych lub częściowo odpłatnych świadczeń oraz świadczeń w naturze) niezbędne jest ich zdefiniowanie przez ustawowe wyliczenie konstytutywnych cech takich świadczeń,

- ze względu na otwarty i stale rozwijający się katalog świadczeń (pieniężnych oraz naturalnych) oferowanych przez pracodawców na rzecz pracowników nie jest możliwe enumeratywne wyliczenie w ustawie

55 A. Pomorska, Potrzeba wzmocnienia funkcji redystrybucyjnej podatku dochodowego od osób fizycznych [w:] Potrzeba i kierunki reformy podatków dochodowych w Polsce, red. A. Pomorska, Wydawnictwo KUL, Lublin 2016, s. 48.

${ }^{56}$ J. Kulicki, Reforma opodatkowania dochodów [w:] Dylematy reformy systemu podatkowego w Polsce, red. H. Dzwonkowski, J. Kulicki, Wydawnictwo Sejmowe, Warszawa 2016, s. 350 . 
podatkowej wszystkich takich świadczeń, które wprost byłyby nazwane przychodami z pracy najemnej (konieczne jest zatem stosowanie w ustawie podatkowej definicji opisowych poszczególnych kategorii przychodów pracowniczych, np. świadczeń nieodpłatnych, świadczeń częściowo odpłatnych, świadczeń pieniężnych ponoszonych za pracownika),

- w związku z tym, że praca może być i de facto jest wykonywana w różnych warunkach, $w$ tym czasowych lub związanych $z$ określonymi ryzykami, przychody z niej uzyskiwane nie powinny być opodatkowywane według takich samych zasad, ponieważ prowadzi to do nierównego opodatkowania (większe ryzyko związane ze świadczoną pracą lub inne istotne uciążliwości towarzyszące wykonywaniu pracy powinny znajdować odzwierciedlenie w odpowiedniej cenie, tj. wynagrodzeniu za pracę, a więc określone rodzaje przychodów uzyskane w takich warunkach należy obciążyć niższą daniną),

- świadczeniu pracy towarzyszą różne zjawiska ekonomiczne (np. inflacja, deflacja), dlatego celowe jest przywrócenie ustawowo określonych mechanizmów waloryzacyjnych, gwarantujących utrzymywanie już po opodatkowaniu odpowiedniej wartości dochodów uzyskiwanych z pracy najemnej (w szczególności mechanizm ten powinien obejmować kwotowe limity kosztów uzyskania przychodów).

Celem proponowanych reform jest nie tylko usunięcie dotychczas zidentyfikowanych problemów związanych ze stosowaniem poszczególnych przepisów ustawy podatkowej, regulujących zasady opodatkowania dochodów z pracy najemnej, ale przede wszystkim bardziej precyzyjne wyznaczenie granic przedmiotowych tego źródła przychodów, a więc pełniejsza realizacja standardów konstytucyjnych odnoszących się do prawa podatkowego.

\section{Bibliografia}

Bartoszewicz M., Zakolska J., Glosa do wyroku sądu okręgowego z dnia 20 maja 2003 r., IV Ka 893/02, „Przegląd Legislacyjny” 2003, nr 5.

Boguska A., Konstrukcja delegowania pracowników w celu świadczenia usług na poziomie unijnym i w praktyce prawa polskiego, „Monitor Prawa Pracy” 2016, nr 2.

Borszowski P., Glosa do wyroku NSA z dnia 14 listopada 2003 r., I SA/Łd 1493/2002, „Przegląd Orzecznictwa Podatkowego” 2005, nr 2.

Bosak M., Majka P., Charakter prawny pracowniczych świadczeń nieodpłatnych w świetle regulacji prawa pracy oraz prawa podatkowego, „Studia z Zakresu Prawa Pracy i Polityki Społecznej" 2013, nr 1.

Brzeziński B., Glosa do wyroku NSA z dnia 17 maja 2013 r., II FSK 1812/11, „Orzecznictwo Sądów Powszechnych” 2014, nr 1, poz. 10. 
Dębowska-Romanowska T., Prawo finansowe. Część konstytucyjna wraz z częścią ogólna, C.H. Beck, Warszawa 2010.

Kulicki J., Reforma opodatkowania dochodów [w:] Dylematy reformy systemu podatkowego w Polsce, red. H. Dzwonkowski, J. Kulicki, Wydawnictwo Sejmowe, Warszawa 2016.

Kuźniacki B., Opodatkowanie zysków z tytułu usług budowlano-montażowych $w$ świetle polsko-norweskiej umowy o unikaniu podwójnego opodatkowania: Pojęcie stałego zakładu usługowego, „Monitor Podatkowy” 2013, nr 3.

Major T., Pawłowska B., Ubezpieczenia społeczne pracowników delegowanych. Nowe przepisy obowiazujace od 2010 r., „Monitor Prawa Pracy” 2010, nr 6.

Mariański A., Strzelec D., Glosa do uchwały NSA z dnia 24 maja 2010 r., II FPS 1/10, „Przegląd Podatkowy” 2010, nr 9.

Mastalski R., Glosa do uchwały NSA z dnia 24 maja 2010 r., II FPS 1/10, „Orzecznictwo Sądów Powszechnych" 2010, nr 12, poz. 121.

Nykiel W., Mariański A., Wilk M., Komentarz do art. 22 [w:] Komentarz do ustawy o podatku dochodowym od osób fizycznych, red. W. Nykiel, A. Mariański, ODDK, Gdańsk 2015.

Pomorska A., Potrzeba wzmocnienia funkcji redystrybucyjnej podatku dochodowego od osób fizycznych [w:] Potrzeba i kierunki reformy podatków dochodowych w Polsce, red. A. Pomorska, Wydawnictwo KUL, Lublin 2016.

Pustuł J., Imprezy integracyjne a przychód z nieodpłatnych świadczeń, „Przegląd Podatkowy" 2013, nr 9.

Strzelec D., Komentarz do art. 12 [w:] Komentarz do ustawy o podatku dochodowym od osób fizycznych, red. W. Nykiel, A. Mariański, ODDK, Gdańsk 2015.

Wspólnotowe prawo gospodarcze, t. I (Swobody rynku wewnętrznego), red. A. Cieśliński, C.H. Beck Warszawa 2008.

\section{Akty prawne}

Konstytucja Rzeczypospolitej Polskiej z 2 kwietnia 1997 r., Dz.U. nr 78, poz. 483, ze zm. Ustawa z 16 lipca 1920 r. o państwowym podatku dochodowym i podatku majątkowym, Dz.U. RP nr 82, poz. 550, ze zm.

Ustawa z 22 października 1931 r. o kryzysowym dodatku do państwowego podatku dochodowego, Dz.U. RP 1935, nr 45, poz. 311, ze zm.

Ustawa z 28 marca 1933 r. o ubezpieczeniu społecznym, Dz.U. RP nr 51, poz. 396, ze zm. Ustawa z 4 lutego 1949 r. o podatku od wynagrodzeń, Dz.U. nr 7, poz. 41, ze zm.

Ustawa z 16 grudnia 1972 r. o podatku dochodowym, Dz.U. 1989, nr 27, poz. 147, ze zm. Ustawa z 26 czerwca 1974 r. - Kodeks pracy, t.j. Dz.U. 2018, poz. 917, ze zm.

Ustawa z 26 lutego 1982 r. o opodatkowaniu jednostek gospodarki uspołecznionej, Dz.U. 1987, nr 12, poz. 77, ze zm.

Ustawa z 28 lipca 1983 r. o podatku wyrównawczym, Dz.U. nr 42, poz. 188, ze zm.

Ustawa z 26 lipca 1991 r. o podatku dochodowym od osób fizycznych, t.j. Dz.U. 2018, poz. 200, ze zm. 
Ustawa z 29 listopada 2000 r. o zbieraniu i wykorzystywaniu danych rachunkowych z gospodarstw rolnych, Dz.U. 2001, nr 3, poz. 20, ze zm.

Ustawa z 10 października 2002 r. o minimalnym wynagrodzeniu za pracę, t.j. Dz.U. 2017, poz. 847.

Ustawa z 15 grudnia 2016 r. o zasadach unikania podwójnego opodatkowania oraz zapobiegania uchylaniu się od opodatkowania w zakresie podatków od dochodu stosowanych przez Rzeczpospolitą Polską i terytorium, do którego stosuje się prawo podatkowe należące do właściwości Ministra Finansów Tajwanu, Dz.U. poz. 2244.

Konwencja z 13 lutego 2002 r. między Rzecząpospolitą Polską a Królestwem Niderlandów w sprawie unikania podwójnego opodatkowania i zapobiegania uchylaniu się od opodatkowania w zakresie podatków od dochodu, Dz.U. 2003, nr 216, poz. 2120.

Konwencja z 8 czerwca 2009 r. między Rzecząpospolitą Polską a Republiką Finlandii w sprawie unikania podwójnego opodatkowania i zapobiegania uchylaniu się od opodatkowania w zakresie podatków od dochodu, Dz.U. 2010, nr 37, poz. 205.

Umowa z 8 października 2013 r. między Rzecząpospolitą Polską a Baliwatem Guernsey w sprawie unikania podwójnego opodatkowania niektórych kategorii dochodów osób fizycznych, Dz.U. 2014, poz. 1341

Rozporządzenie Prezesa Rady Ministrów z 28 kwietnia 2010 r. w sprawie określenia wzorów formularzy sprawozdawczych, objaśnień co do sposobu ich wypełniania oraz wzorów kwestionariuszy i ankiet statystycznych stosowanych w badaniach statystycznych ustalonych w programie badań statystycznych statystyki publicznej na rok 2010, Dz.U. nr 106, poz. 676 ze zm.

Zarządzenie nr 50 Prezesa Kasy Rolniczego Ubezpieczenia Społecznego z 18 listopada 2016 r. w sprawie wprowadzenia instrukcji techniczno-biurowej w zakresie wykonywania zadań dotyczących podlegania ubezpieczeniu społecznemu rolników i ubezpieczeniu zdrowotnemu oraz rozliczeń z tytułu składek na te ubezpieczenia, Dz.Urz. KRUS 2016, poz. 52. 